NBER WORKING PAPER SERIES

\title{
THE STATE OF U.S. CORPORATE GOVERNANCE: WHAT'S RIGHT AND WHAT'S WRONG?
}

\author{
Bengt Holmstrom \\ Steven N. Kaplan \\ Working Paper 9613 \\ http://www.nber.org/papers/w9613
NATIONAL BUREAU OF ECONOMIC RESEARCH 1050 Massachusetts Avenue Cambridge, MA 02138
April 2003

Warren Batts, Don Chew, Art Kelly, Rick Melcher, Andrew Nussbaum, and Per Stromberg provided helpful comments. Address correspondence to Steven Kaplan, Graduate School of Business, The University of Chicago, 1101 East 58th Street, Chicago, IL 60637 or e-mail at steven.kaplan@gsb.uchicago.edu. Part of this article draws on our earlier article, "Corporate Governance and Takeovers in the U.S.: Making Sense of the '80s and '90s," Journal of Economic Perspectives (2001), pp.121-144. The views expressed herein are those of the authors and not necessarily those of the National Bureau of Economic Research.

C2003 by Bengt Holmstrom and Steven N. Kaplan. All rights reserved. Short sections of text not to exceed two paragraphs, may be quoted without explicit permission provided that full credit including Cnotice, is given to the source. 
The State of U.S. Corporate Governance: What's Right and What's Wrong?

Bengt Holmstrom and Steven N. Kaplan

NBER Working Paper No. 9613

April 2003

JEL No. G3, L2

\section{ABSTRACT}

The U.S. corporate governance system has recently been heavily criticized, largely as a result of failures at Enron, WorldCom, Tyco and some other prominent companies. Those failures and criticisms, in turn, have served as catalysts for legislative change (Sarbanes-Oxley Act of 2002) and regulatory change (new governance guidelines from the NYSE and NASDAQ). In this paper, we consider two questions. First, is it clear that the U.S. system has performed that poorly; is it really that bad? Second, will the changes lead to an improved U.S. corporate governance system? We first note that the broad evidence is not consistent with a failed U.S. system. The U.S. economy and stock market have performed well both on an absolute basis and relative to other countries over the past two decades. And the U.S. stock market has continued to outperform other broad indices since the scandals broke. Our interpretation of the evidence is that while parts of the U.S. corporate governance system failed under the exceptional strain of the 1990s, the overall system, which includes oversight by the public and the government, reacted quickly to address the problems. We then consider the effects that the legislative, regulatory, and market responses are likely to have in the near future. Our assessment is that they are likely to make a good system better, though there is a danger of overreacting to extreme events.

Bengt Holmstrom

Department of Economics

MIT

E52-271d

Cambridge, MA 02139

and NBER

bengt@mit.edu
Steven N. Kaplan

Graduate School of Business

The University of Chicago

1101 East $58^{\text {th }}$ Street

Chicago, IL 60637

and NBER

steven.kaplan@gsb.uchicago.edu 
To a casual observer, the United States corporate governance system must seem to be in terrible shape. The business press has focused relentlessly on the corporate board and governance failures at Enron, WorldCom, Tyco, Adelphia, Global Crossing, and others. Top executive compensation is also routinely criticized as excessive by the press, academics, and even top Federal Reserve officials. ${ }^{1}$ These failures and concerns, in turn, have served as catalysts for legislative change-in the form of the Sarbanes-Oxley Act of 2002 - and regulatory change, including new governance guidelines from the NYSE and NASDAQ.

The turmoil and the responses to it suggest two important questions that we attempt to answer in this article. First, has the U.S. corporate governance system performed that poorly--is it really that bad? Second, will the proposed changes lead to a more effective system?

In addressing the first question, we begin by examining two broad measures of economic performance for evidence of failure of the U.S. system. Despite the alleged flaws in its governance system, the U.S. economy has performed very well, both on an absolute basis and particularly relative to other countries. U.S. productivity gains in the past decade have been exceptional, and the U.S. stock market has consistently outperformed other world indices over the last two decades, including the period since the scandals broke. In other words, the broad evidence is not consistent with a failed U.S. system. If anything, it suggests a system that is well above average.

Next, we discuss how important aspects of the U.S. corporate governance system have evolved over the last two decades and the implications of those changes. Again, contrary to the popular impression, the major changes in U.S. corporate governance in the past 20 years-

\footnotetext{
${ }^{1}$ For example, see Marco Becht, Patrick Bolton, and Ailsa Roell, "Corporate Governance and Control," in Handbook of Economics and Finance (G. Constantinides, M. Harris, and R. Stulz, eds.). North Holland (2002), "CEOs Are Overpaid, Says Fed Banker," The Washington Post, September 11, 2002, and "After 10 Years, Corporate Oversight Is Still Dismal,” by Claudia Deutsch, The New York Times, January 26, 2003.
} 
notably, the dramatic increase in equity-based pay and the institutionalization of U.S.

shareholders--appear to have been positive overall. As we discuss below, such changes played a central role in the highly productive restructuring of U.S. corporations that took place during the 1980s and 1990s. But the changes did have an unfortunate side effect. Besides spurring productivity improvements, the rise of equity-based pay--particularly the explosion of stock options--and the run-up in stock prices in the late ' 90 s created incentives for the shortsighted and at times illegal managerial behavior that has attracted so much criticism. Our view, however, is that the costs associated with such incentives and behavior have been far outweighed by the benefits.

Having addressed where the U.S. system is today and how it got there, we finally consider the probable near-term effects of the legislative, regulatory, and market responses to the perceived governance "problem." We conclude that the current changes are likely to make a good U.S. system a better one, although not without imposing some unnecessary costs. In fact, the greatest risk now facing the U.S. corporate governance system is the possibility of overregulation.

\section{HOW BAD IS U.S. CORPORATE GOVERNANCE?}

Given the volume and intensity of criticism of U.S. corporate governance, one would think that the U.S. stock market must have performed quite badly, particularly since the scandals broke in 2001. But, the data summarized in Table 1 indicate otherwise. Table 1 reports the total returns (measured in dollars) to the Morgan Stanley Capital International indices for the aggregate U.S., European, and Pacific stock markets over five different time periods through the end of 2002. Although the U.S. stock market has had negative returns over the last several years, 
it has performed well relative to other stock markets, both recently and over the longer term. In fact, the U.S. market has generated returns at least as high as those of the European and Pacific markets during each of the five time periods considered--since 2001, since 1997, since 1992, since 1987, and since 1982. The returns to the U.S. stock market also compare favorably to the returns of the stock markets of the larger individual countries (including France, Germany, Great Britain, and Japan) that make up the indices.

Because many factors affect stock returns, it would be inappropriate to claim that superior U.S. corporate governance explains the differences in returns. We can conclude, however, that whatever the shortcomings of the U.S. system, they have not been sufficiently great to prevent the stock returns of U.S. companies from outperforming those of the rest of the world.

It is worth pointing out two additional implications of the stock performance results. First, the returns to U.S. stocks have been at least as large as the returns to European and Pacific stocks since 2001, the period in which the U.S. corporate governance scandals first emerged. One possible explanation is that the effects of the governance scandals on U.S. stock values have not been particularly large relative to other factors that have weighed on most national economies. Another possibility is that while there may be some problems with the U.S. corporate governance system, the problems confronting the governance systems of other nations are even worse. But in our view, the most plausible explanation is that while parts of the U.S. system failed under the exceptional strain of the 1990s' boom market, the damage was limited because the overall system reacted quickly to address the problems.

The second important point to keep in mind about stock returns is that they reflect publicly available information about executive compensation. Returns, therefore, are measured 
net of executive compensation payments. The fact that the shareholders of U.S. companies earned higher returns even after payments to management does not support the claim that the U.S. executive pay system is designed inefficiently; if anything, shareholders appear better off with the U.S. system of executive pay than with the systems that prevail in other countries. As we discuss later, however, the higher U.S. returns do not rule out the possibility that some top U.S. executives are paid more than is necessary for incentive purposes and that our incentive pay system can be improved.

Overall country productivity provides another broad measure of performance. Again, one might expect a less effective corporate governance system to lead to lower productivity growth. Table 2 presents calculations of the percentage change in GDP per capita for developed countries since 1982. The results do not suggest the presence of an ineffective U.S. governance system. From the beginning of 1992 to the end of $2000,{ }^{2}$ growth in GDP per capita was greater in the U.S. than in France, Germany, Great Britain, or Japan. And given the strong U.S. productivity numbers through the recent downturn, this gap has probably widened since then. Again, these results do not necessarily demonstrate that the U.S. corporate governance system is the principal cause of the larger productivity improvements. Many other forces operate at the same time. The results do suggest, however, that any deficiencies in the U.S. corporate governance system have not prevented the U.S. economy from outperforming its global competitors.

\section{CHANGES IN U.S. CORPORATE GOVERNANCE OVER THE LAST 20 YEARS $^{3}$}

\footnotetext{
${ }^{2}$ This is the most recent period for which data are available.

${ }^{3}$ This section summarizes some of the arguments in Bengt Holmstrom and Steven Kaplan, "Corporate Governance and Takeovers in the U.S.: Making Sense of the '80s and '90s," Journal of Economic Perspectives, pp. 121-144
} 
Corporate governance in the U.S. has changed dramatically since 1980. As a number of business and finance scholars have pointed out, the corporate governance structures in place before the 1980s gave the managers of large public U.S. corporations little reason to make shareholder interests their primary focus. Before 1980, corporate managements tended to think of themselves as representing not the shareholders, but rather "the corporation." In this view, the goal of the firm was not to maximize shareholder wealth, but to ensure the growth (or at least the stability) of the enterprise by "balancing" the claims of all important corporate "stakeholders"-employees, suppliers, and local communities, as well as shareholders. ${ }^{4}$

The external governance mechanisms available to dissatisfied shareholders were seldom used. Raiders and hostile takeovers were relatively uncommon. Proxy fights were rare and didn't have much chance of succeeding. And corporate boards tended to be cozy with and dominated by management, making board oversight weak.

Internal incentives from management ownership of stock and options were also modest. For example, in 1980 only $20 \%$ of the compensation of U.S. CEOs was tied to stock market performance. ${ }^{5}$ Long-term performance plans were widely used, but they were typically based on accounting measures like sales growth and earnings per share that tied managerial incentives less directly, and sometimes not at all, to shareholder value.

Partly in response to the neglect of shareholders, the 1980s ushered in a large wave of takeover and restructuring activity. This activity was distinguished by its use of hostility and aggressive leverage. The 1980s saw the emergence of the corporate raider and hostile takeovers.

(Spring 2001) and Steven Kaplan, "The Evolution of U.S. Corporate Governance: We Are All Henry Kravis Now," Journal of Private Equity, pp. 7-14 (1997).

${ }^{4}$ See Gordon Donaldson and Jay Lorsch, Decision Making at the Top (Basic Books, New York, 1983), and Michael Jensen, "The Modern Industrial Revolution," Journal of Finance, pp. 831-880 (1993).

${ }^{5}$ See Brian Hall and Jeffrey Liebman, "Are CEOs Really Paid like Bureaucrats?" Quarterly Journal of Economics, 112, pp. 653-691 (1998). 
Raiders like Carl Icahn and T. Boone Pickens became household names. Nearly half of all major U.S. corporations received a takeover offer in the 1980s--and many companies that were not taken over responded to hostile pressure with internal restructurings that made themselves less attractive targets. ${ }^{6}$

The use of debt financing by U.S. companies was so extensive that, from 1984 to 1990 , more than $\$ 500$ billion of equity was retired (net of new equity issuances), as many firms repurchased their own shares, borrowed to finance takeovers, or were taken private in leveraged buyouts (LBOs). As a result, corporate leverage ratios increased substantially. Leveraged buyouts were extreme in this respect, with debt levels typically exceeding $80 \%$ of total capital.

In the 1990s, the pattern of corporate governance activity changed again. After a steep but brief drop in merger activity around 1990, takeovers rebounded to the levels of the 1980s. Hostility and leverage, however, declined substantially. At the same time, other corporate governance mechanisms began to play a larger role, particularly executive stock options and the greater involvement of boards of directors and shareholders.

The preponderance of the evidence is consistent with an overall explanation as follows: In the early 1980s, the wedge between actual and potential corporate performance became increasingly apparent. In some cases, changes in markets, technology, or regulation led to a large amount of excess capacity--for example, in the oil and tire industries. In others, it became apparent that diversification strategies carried out in the late ' 60 s and ' 70 s were underperforming. ${ }^{7}$ The top managers of such companies, however, were slow to respond to opportunities to increase value. As mentioned above, limited ownership of stock and options

\footnotetext{
${ }^{6}$ See Mark Mitchell and Harold Mulherin, "The Impact of Industry Shocks on Takeover and Restructuring Activity,” Journal of Financial Economics, pp. 193-229 (1996).

${ }^{7}$ See Jensen (1993), cited earlier, and Andrei Shleifer and Robert Vishny, "The Takeover Wave of the 1980s," Science, 249, August 17, pp. $745-749$ (1990).
} 
gave managers little monetary incentive to make major changes that might weaken their "partnership" with other corporate stakeholders. But perhaps equally important, some corporate leaders persisted in their conviction that growth and stability were the "right" corporate goals and they simply refused to believe what the capital markets were telling them. This appears to have been true, for example, of the U.S. oil industry in the early 1980s, when oil companies traded below the value of their oil holdings because of industry-wide overinvestment in exploration.

At the same time many U.S. companies were failing to maximize value, the U.S. capital markets were becoming more powerful because of increased stock ownership by large institutions. It was the potential for improved corporate performance combined with the increased ownership of institutional investors that gave birth to the takeovers, junk bonds, and LBOs of the 1980s. In some cases, the capital markets reversed ill-advised diversification through "bust-up" transactions (such as KKR's acquisition of Beatrice Foods in 1986). In other cases, the financial markets effectively forced managers to eliminate excess capacity (as in Chevron's leveraged acquisition of Gulf Oil in 1984). More generally, the capital markets disciplined managers who had ignored shareholders for the benefit of themselves and other stakeholders. As we discuss below, the incentive and governance features of LBOs are particularly representative of the discipline that the capital markets imposed.

The initial response of U.S. executives was to fight takeovers with legal maneuvers and to attempt to enlist political and popular support against corporate raiders. Over time, these efforts met with some legislative, regulatory, and judicial success. As a result, hostile takeovers became far more costly in the 1990s than in the previous decade.

But the accomplishments of the 1980s were by no means forgotten. By the 1990s U.S. managers, boards, and institutional shareholders had seen what LBOs and other market-driven 
restructurings could do. With the implicit assent of institutional investors, boards substantially increased the use of stock option plans that allowed managers to share in the value created by restructuring their own companies. Shareholder value thus became an ally rather than a threat.

This general embrace of shareholder value helps to explain why restructurings continued at a high rate in the $1990 \mathrm{~s}$, but for the most part on amicable terms. There was also less of a need for high leverage because deals could now be paid for with stock without raising investors' concerns that managers would pursue their own objectives at the expense of shareholders.

The merger wave of the 1990s also appears to have had a somewhat different purpose than the wave of the 1980s, representing a different stage in the overall restructuring process. The deals of the 1980s were more of a bust-up wave whose main effect was to force corporate assets out of the hands of managers who could not or would not use them efficiently. The transactions of the 1990s, by contrast, had more of a "build-up" effect in which assets were reconfigured to take advantage of growth opportunities in new technologies and markets. This logic also fits with the increased use of equity rather than debt in funding the deals of the 1990s.

The move toward shareholder value and increased capital market influence has also been apparent in the way corporations have reorganized themselves. For example, there has been a broad trend toward decentralization. Large companies have been working hard to become more nimble and to find ways to offer employees higher-powered incentives. At the same time, external capital markets have taken on a larger role in capital reallocation, as evidenced by the large volume of mergers and divestitures throughout the '90s. During the same period, the amounts of funds raised and invested by U.S. venture capitalists--who help perform the key 
economic function of transferring funds from mature to new high-growth industries--also increased by an order of magnitude over the $1990 \mathrm{~s}^{8}$

In sum, while corporate managers still reallocate vast amounts of resources in the economy through internal capital and labor markets, the boundary between markets and managers appears to have shifted. As managers have ceded authority to the markets, the scope and independence of their decision-making have narrowed.

We now focus more specifically on changes in three key elements of the U.S. (and indeed any) corporate governance system: executive compensation, shareholders, and boards of directors.

\section{Changes in Executive Compensation}

The total pay of top U.S. executives, particularly option-based compensation, has increased substantially over the last two decades. For example, a study published in the late '90s reported that during the 15-year period from 1980 to 1994, the average compensation of CEOs of large U.S. companies tripled in real terms. The study also concluded that the average annual CEO option grant (valued at issuance) increased roughly sevenfold and, as a result, equity-based compensation in 1994 made up almost 50\% of total CEO compensation (up from less than 20\% in 1980). ${ }^{9}$ Moreover, as reported in a more recent study, this trend continued from 1994 to 2001, with CEO pay more than doubling and option-based compensation increasing at an even faster rate. $^{10}$

\footnotetext{
${ }^{8}$ See Raghu Rajan and Julie Wulf, “The Flattening Firm," working paper, University of Chicago (2002), and Paul Gompers and Josh Lerner, "The Venture Capital Revolution," Journal of Economic Perspectives, pp. 145-168 (2001).

${ }^{9}$ Hall and Liebman (1998), cited earlier.

${ }^{10}$ See Brian Hall and Kevin Murphy, "Stock Options for Undiversified Executives," Journal of Accounting and Economics, pp. 3-42 (2002) and Brian Hall, "Six Challenges in Designing Equity-Based Pay," in this issue of the $J A C F$.
} 
Overall, then, CEO compensation appears to have increased by a factor of six over the last two decades, with a disproportionate increase in equity-based compensation. The effect of the increase in equity-based compensation has been to increase CEO pay-to-performance sensitivities by a factor of more than ten times from 1980 to $1999 .^{11}$

These increases in executive compensation, particularly options, have generated enormous controversy. The recent scandals and stock market declines have led some observers to argue that such increases represent unmerited transfers of shareholder wealth to top executives with limited if any beneficial incentive effects. For example, one recent survey of corporate governance concludes: "It is widely recognized...that these options are at best an inefficient financial incentive and at worst create new incentive or conflict-of-interest problems of their own."12

There are several reasons to be skeptical of these conclusions. First, as we have already pointed out, the performance of the U.S. stock market and the strong growth in U.S. productivity provide no support for such arguments.

Second, the primary effect of the large shift to equity-based compensation has been to align the interests of CEOs and their management teams with shareholders' interests to a much greater extent than in the past. Large stock option grants fundamentally changed the mind-set of CEOs and made them much more receptive to value-increasing transactions. The tenfold increase in pay-for-performance sensitivities implies that a one dollar increase in a company's stock price was ten times more valuable to a CEO at the end of the 1990s than at the beginning

\footnotetext{
${ }^{11}$ The levels of executive compensation and managerial equity ownership appear to be high not only relative to 1980, but also relative to earlier periods. Holderness, Kroszner, and Sheehan compare equity ownership by officers and directors in 1935 and 1995 and find that equity ownership was substantially greater in 1995 than in 1935. See Cliff Holderness, Randall Kroszner, and Dennis Sheehan, "Were the Good Old That Good? Changes in Managerial Stock Ownership Since the Great Depression,” Journal of Finance, pp. 435-470 (1999).
} 
of the 1980s. As we noted earlier, this shift played a significant role in the continued restructuring of corporations in the 1990s. ${ }^{13}$ It also helps explain the 1997 decision of the Business Roundtable--a group of 200 CEOs of the largest American companies--to change its position on business objectives (after years of opposition and ambivalence to shareholder value) to read "the paramount duty of management and the board is to the shareholder and not to...other stakeholders."

A third reason to be skeptical of the criticism of U.S. top executive pay practices is that both buyout investors and venture capital investors have made, and continue to make, substantial use of equity-based and option compensation in the firms they invest in. A 1989 study by one of the authors reported that the CEOs of companies taken private in LBOs increased their ownership stake by more than a factor of four, from an average of $1.4 \%$ before the LBO to $6.4 \%$ after. The study also found that management teams as a whole typically obtained $10 \%$ to $20 \%$ of the post-buyout equity. ${ }^{14}$ More recent research and anecdotal evidence suggest that such levels of managerial equity ownership are still typical in today's buyout transactions. ${ }^{15}$

This feature of LBOs is particularly notable. LBO sponsor firms such as KKR, Texas Pacific Group, and Thomas Lee typically buy majority control of the companies they invest in through the partnerships that the sponsors manage. The individual partners of the LBO sponsors have strong incentives to make profitable investments since the sponsors typically receive $20 \%$

\footnotetext{
${ }^{12}$ See Marco Becht, Patrick Bolton, and Ailsa Roell, (2002), ibid. See also, Lucian Bebchuk, Jesse Fried, and David Walker, "Managerial Power and Rent Extraction in the Design of Executive Compensation," University of Chicago Law Review, pp. 751-846 (2002).

${ }^{13}$ For additional evidence consistent with this conclusion, see John Core and David Larcker, "Performance Consequences of Mandatory Increases in Executive Stock Ownership," Journal of Financial Economics (2002), who find that option grants or increases in equity ownership are related to improvements in stock and accounting performance.

${ }^{14}$ See Steven Kaplan, "The Effects of Management Buyouts on Operations and Value," Journal of Financial Economics, pp. 217-254 (1989).

${ }^{15}$ P. Rogers, T. Holland, and D. Haas, "Value Acceleration: Lessons from Private-Equity Masters," Harvard Business Review, June (2002).
} 
of the profits of a particular buyout partnership, and the sponsors' ability to raise other funds is strongly related to the performance of their existing investments. ${ }^{16}$ And the fact that such sponsors also insist on providing the managers of their companies with high-powered incentives suggests that incentives have been a critical ingredient in the success of LBOs.

Two other aspects of compensation contracts designed by LBO sponsors for the top executives of their portfolio companies are worth mentioning. First, the equity and options held by those top executives are typically illiquid--usually by necessity because most of the companies are private--unless and until the company has clearly succeeded through an IPO or a sale to another company. This means that top management cannot trade in and out of the stock (nor can it easily hedge its positions). Second, neither LBO sponsors nor venture capitalists typically index the executive compensation contracts they employ to industry performance or market performance. If nonindexed options and equity grants were so inefficient, as critics of executive compensation have argued, we would expect to see more indexing of private equity contracts.

Unfortunately, while the greater use of stock-based compensation has likely been a positive development overall, critics of the U.S. governance system are correct in pointing out that higher-powered incentives have not come without costs. ${ }^{17}$

First, as executive stock and option ownership have increased, so has the incentive to manage and manipulate accounting numbers in order to inflate stock market values and sell

\footnotetext{
${ }^{16}$ See Steven Kaplan and Antoinette Schoar, "Private Equity Returns: Persistence and Capital Flows," working paper, University of Chicago, December (2002).

${ }^{17}$ Other critiques are offered in Lucien Bebchuk, Jesse Fried, and David Walker, "Managerial Power and Rent Extraction in the Design of Executive Compensation," University of Chicago Law Review 69 (2002), pp. 751-846, Becht, Bolton, and Roell, (2002) ibid., Brian Hall "Equity-Pay Design for Executives," working paper, Harvard Business School (2002), and Tod Perry and Marc Zenner "CEO Compensation In The 1990s: Shareholder Alignment Or Shareholder Expropriation?” Wake Forest Law Review (2001).
} 
shares at those inflated values. ${ }^{18}$ This arguably was important in the cases of Global Crossing and WorldCom, among others.

Second, and related to the first, much of the compensation of top U.S. executives is fairly liquid — and, as we argue below, considerably more liquid than shareholders would like it to be. Unlike LBO sponsors, boards do not put strong restrictions on the ability of top executives to unwind their equity-based compensation by exercising options, selling shares, or using derivatives to hedge their positions. And finding a workable solution to the problem of optimal liquidity for top executive compensation is an important challenge faced by today's boards.

Third, most options are issued at the money because accounting rules do not require the cost of such options to be expensed. It is plausible that because the cost of the options does not appear as an expense, some boards of directors underestimate the options' cost. It is undeniable that the size of some of the option grants has been far greater than what is necessary to retain and motivate the CEOs. In 2001, for example, the ten most highly rewarded CEOs in the S\&P 500 were granted option packages with an estimated average value (at time of grant) of $\$ 170$ million per person. Even if some of these grants represent multiyear awards, the amounts are still staggering. It is particularly disconcerting that among the executives receiving the largest grants in the past three years, several already owned large amounts of stock, including Larry Ellison of Oracle, Tom Siebel of Siebel Systems, and Steve Jobs of Apple. It is hard to argue that these people need stronger shareholder incentives. An obvious explanation is that they have been able to use their positions of power to command excessive awards.

\footnotetext{
${ }^{18}$ See Jeremy Stein "Efficient Capital Markets, Inefficient Firms: A Model of Myopic Corporate Behavior," Quarterly Journal of Economics, Vol. 104, pp. 655-669 (1989) for a model explaining this behavior. See also Joseph Fuller and Michael Jensen, "Just Say No to Wall Street," Journal of Applied Corporate Finance, Vol. 14 No. 4 (2002).
} 
Even so, it would be a mistake to condemn the entire system based on a few cases. That such cases are far from representative can be seen from the pronounced skew in the distribution of CEO incomes. In 2001, for example, the same year the top ten U.S. CEOs received average option grants of $\$ 170$ million, the median value of total compensation for CEOs of S\&P 500 companies was about $\$ 7$ million. Thus, U.S. executive pay may not be quite the runaway train that has been portrayed in the press. ${ }^{19}$

\section{Changes in Shareholders}

As mentioned above, the composition of U.S. shareholders also has changed significantly over the past two decades. Large institutional investors own an increasingly large share of the overall stock market. For example, from 1980 to 1996, large institutional investors nearly doubled their share of ownership of U.S. corporations from less than $30 \%$ to more than $50 \%$. (Conversely, individual ownership declined from $70 \%$ in 1970 to $60 \%$ in 1980 and to $48 \%$ in 1994. ${ }^{20}$ )

There are at least two reasons public company shareholders are likely to monitor management more effectively today than in the 1980s. First, the large increase in the shareholdings of institutional investors means that professional investors--who have strong incentives to generate greater stock returns and are presumably more sophisticated--own an increasingly large fraction of U.S. corporations.

Second, in 1992 the SEC substantially reduced the costs to shareholders of challenging management teams. Under the old rules, a shareholder had to file a detailed proxy statement

\footnotetext{
${ }^{19}$ A part of the problem is that the press has traditionally reported the value of exercised options instead of the value of options at the time they have been granted. This is changing, too.
} 
with the SEC before talking to more than ten other shareholders. Under the new rules, shareholders can essentially communicate at any time and in any way as long as they send a copy of the substance of the communication to the SEC afterward. The rule change has lowered the cost of coordinating shareholder actions and blocking management proposals. (Not surprisingly, the Business Roundtable and other management organizations were extremely hostile to this rule change when it was proposed.)

Consistent with these two changes, shareholder activism has increased in the U.S. since the late 1980s. The evidence on the impact of such activism, however, is mixed. For example, a 1998 summary of the results of 20 empirical studies of the effects of formal shareholder proposals and private negotiations with managements reported evidence of small or no effects on shareholder value. ${ }^{21}$ When interpreting such evidence, however, it is important to keep in mind the difficulty of measuring the extent and effects of shareholder activity, in part because so much of this activity takes place behind the scenes and is not reported. And the fact that a recent study reported that stock returns over the period 1980-1996 were higher for companies with greater institutional ownership suggests that our large institutions may indeed be playing a valuable monitoring role- one that translates into higher stock prices. ${ }^{22}$

\section{Changes in Boards of Directors}

In an influential study of U.S. corporate boards in the second half of the 1980s, Jay Lorsch and Elizabeth MacIver pointed out a number of deficiencies and offered several

\footnotetext{
${ }^{20}$ See Paul Gompers and Andrew Metrick, "Institutional Investors and Equity Prices, " Quarterly Journal of Economics (2001), and James Poterba and Andrew Samwick, "Stock Ownership Patterns, Stock Market Fluctuations, and Consumption," Brookings Papers on Economic Activity, pp. 295-357 (1995).

${ }^{21}$ Jonathan Karpoff, "The Impact of Shareholder Activism on Target Companies: A Survey of Empirical Findings," Working paper, University of Washington (1998).

22 Paul Gompers and Andrew Metrick, "Institutional Investors and Equity Prices," Quarterly Journal of Economics, Vol. 116 (1), 2001, pp. 229-260.
} 
recommendations. Chief among them were the following: (1) board selection by a nominating committee rather than the $\mathrm{CEO}$; (2) more equity compensation for directors; and (3) more director control of board meetings through appointment of a lead director or outside chairman, annual CEO reviews, and regular sessions with outside directors only ("executive sessions"). ${ }^{23}$

Since the publication of that study in 1989, the boards of U.S. companies have made progress in implementing all three of these recommendations. U.S. companies have significantly expanded the use of nominating committees and lead directors. Executive sessions are increasingly common (although, as suggested below, not as common as directors would like). Boards of U.S. companies now include a larger percentage of independent and outside directors, and have become somewhat smaller over time (smaller boards are thought to be more effective in disciplining CEOs and tend to be associated with higher valuations). ${ }^{24}$ Also encouraging, directors today receive a significantly larger amount of their total compensation in the form of stock or options. For example, one study reported that stock-based directors' compensation increased from $25 \%$ in 1992 to $39 \%$ in 1995 , and that trend has since continued. ${ }^{25}$

The CEO turnover process--one of the most widely used measures of the effectiveness of a governance system--suggests that the CEO labor market has become broader and, arguably, more efficient. One recent study of CEO turnover for large companies from 1971 to 1994 found a marked increase in both forced CEO departures and the hiring of new CEOs from outside the company. Within the study, the incidence of forced turnovers and outside succession was highest from 1989 to $1994,{ }^{26}$ a trend that also appears to have continued. The same study

\footnotetext{
${ }^{23}$ Jay Lorsch and Elizabeth MacIver, Pawns or Potentates. Harvard Business School Press (1989).

${ }^{24}$ See David Yermack, "Higher Market Valuation of Companies with a Small Board of Directors," Journal of Financial Economics, Vol. 40, 1996, pp. 185-202.

${ }^{25}$ For a summary of these changes, see Ben Hermalin and Michael Weisbach, "Boards of Directors as an Endogenously Determined Institution: A Survey of the Economic Literature," Economic Policy Review (2003).

${ }^{26}$ See M. Huson, Robert Parrino, and Laura Starks, "Internal Monitoring Mechanisms and CEO Turnover: A LongTerm Perspective," Journal of Finance, pp. 2,265-2,297 (2001).
} 
reported that CEO turnover was more sensitive to poor performance - as measured by reductions in operating income - during the 1989-1994 period than in earlier years. ${ }^{27,28}$

On the negative side, however, antitakeover measures such as poison pills and staggered boards have increased substantially in the past two decades. And recent research finds that over the 1990s, companies with a high level of anti-shareholder provisions experienced substantially lower returns than firms with a low level of such provisions. ${ }^{29}$

Despite the improvements noted above, the recent events at companies like Enron, Tyco, and WorldCom suggest that the boards of U.S. companies continue to exhibit less than the optimal amount of independence and oversight. The Senate report on Enron's board is particularly critical in this respect. When a company is not doing well, everyone pays close attention--lenders and investors as well as board members. But when a company appears to be doing well, as was the case with both Enron and Tyco, investors and the board are likely to be less critical.

A recent survey of more than 2,000 directors by Korn Ferry in early 2002 (and thus before the passage of Sarbanes-Oxley and the issuance of the new NYSE and NASDAQ regulations) is very interesting in this regard. The directors who responded to the survey consistently favored more monitoring than was the practice on the boards on which they served. For example, although $71 \%$ of the directors said they believed boards should hold executive

\footnotetext{
${ }^{27}$ On the other hand, Murphy (1999) finds that CEO turnover is less sensitive to industry-adjusted stock performance from 1990 to 1995 than in earlier years. Kevin J. Murphy, "Executive Compensation." In O. Ashenfelter and D. Card (eds.), Handbook of Labor Economics. North Holland, pp. 2,485-2,525 (1999).

${ }^{28}$ Rakesh Khurana in Searching for a Corporate Savior: The Irrational Quest for Charismatic CEOs, Princeton University Press (2002) has argued that the CEO labor market is flawed because it is overly focused on outsider, charismatic CEOs. The operating performance evidence in Rakesh Khurana and Nitin Nohria, "The Effects of CEO Turnover in Large Industrial Corporations: A Study of the Fortune 200 from 1978-1993," Harvard Business School (1997), however, is not consistent with such a conclusion.

${ }^{29}$ Paul Gompers, Joy Ishi, and Andrew Metrick, "Corporate Governance and Equity Prices," Working Paper 8,449, NBER, 2001.
} 
sessions without the CEO, only $45 \%$ said their boards actually did so. And whereas almost $60 \%$ felt their boards should have a lead director, only $37 \%$ reported that their boards had one.

Our bottom line on boards, then, is that the structure and operating procedures of U.S. corporate boards have improved since the 1980s, but they are still far from perfect.

\section{International Developments}

Indirect evidence of the effectiveness of the U.S. governance system is provided by changes in corporate governance in other countries. In recent years, as the forces of deregulation, globalization, and information technology have continued to sweep across the world economy, other countries have begun to move toward the U.S. model. Traditionally, European and Japanese firms have reallocated capital from sunset industries to sunrise industries mainly through internal diversification. External market interventions of the sort seen in the U.S. were almost unheard of. In the late 1990s, however, Europe experienced a sudden rise in hostile takeovers. In 1999 alone, 34 listed companies in Continental Europe received hostile bids, representing a total value of $\$ 406$ billion (as compared to 52 bids for just $\$ 69$ billion over the entire period 1990-1998). ${ }^{30}$ These transactions included Vodafone's bid for Mannesmann, TotalFina's bid for Elf Aquitaine, and Olivetti's bid for Telecom Italia.

Shareholder activism has also been on the rise, with strong support from American institutional investors. For example, Telecom Italia's attempt to split off its wireless unit (at an unacceptable price) was blocked when TIAA-CREF put pressure on the Italian government. In France, shareholder activists managed to defeat a poison-pill proposal by Rhone-Poulenc. European universal banks also have begun to pay more attention to the value of their financial stakes than to their positions of power. These actions appear to have been very much influenced 
by the U.S. model of market intervention and by the fact that more than $\$ 1$ trillion of U.S. funds have been invested in Western Europe in the 1980s and 1990s.

Another way in which companies can make use of the market to reallocate capital more effectively is to repurchase their own shares. In the last several years, Japan, France, Germany, and several other European countries have relaxed prohibitions or restrictions on share repurchases, and companies in those countries have responded by buying back increasing numbers of shares. Finally, the use of stock options for executives and boards is increasing around the world. Japan recently eliminated a substantial tax penalty on executive stock options, and a 2002 study based on Towers Perrin's yearly surveys reported that the rate of adoption of stock options in Europe has matched that of the U.S. in the 1990s. ${ }^{31}$

In sum, the conventional wisdom on corporate governance has changed dramatically since the 1970s and early 1980s, when the U.S. market-based system was subjected to heavy criticism and the bank-centered systems of Japan and Germany were held up as models. ${ }^{32}$ Since the mid-1980s, the American style of corporate governance has reinvented itself, and the rest of the world seems to be following the U.S. lead.

\section{RECENT REGULATORY CHANGES}

The Sarbanes-Oxley Act (SOX), which was enacted in the summer of 2002, mandated a number of changes in corporate governance for publicly traded companies. The NYSE and NASDAQ also mandated corporate governance changes for firms listed on their respective

\footnotetext{
${ }^{30}$ Rick Escherich and Paul Gibbs, Global Mergers and Acquisitions Review, JP Morgan (2002 April).

${ }^{31}$ Brian Hall, "Incentive Strategy II: Executive Compensation and Ownership Structure," Harvard Business School, Teaching Note N9-902-134 (2002).

${ }^{32}$ See for example Michael Porter, “Capital Disadvantage: America's Failing Capital Investment System,” Harvard Business Review, September-October (1992), pp. 65-83.
} 
exchanges. In this section, we discuss the likely effect of these changes on U.S. corporate governance.

\section{Sarbanes-Oxley}

SOX mandated changes that will affect executive compensation, shareholder monitoring, and, particularly, board monitoring.

One provision requires the $\mathrm{CEO}$ and $\mathrm{CFO}$ to disgorge any profits from bonuses and stock sales during the 12-month period that follows a financial report that is subsequently restated because of "misconduct." (We assume this provision also covers any hedging transactions the CEO or CFO undertakes.) Until "misconduct" is clearly defined, this provision increases the risk to a CEO or CFO of selling a large amount of stock or options in any one year while still in office. Some CEOs and CFOs will choose to wait until they are no longer in those positions before selling equity or exercising options. To the extent CEOs and CFOs behave this way, their equity holdings become less liquid and they will care less about short-term stock price movements. This would be a positive change. In addition, the rule will act as a deterrent to negligent or deliberate misreporting. ${ }^{33}$

Shareholder-related provisions include changes in restrictions on insider trading regulation and enhanced financial disclosure. Executives will now have to report sales or purchases of company stock within two days rather than the current ten days, which will have the effect of making executive shares somewhat less liquid. SOX also requires more detailed disclosure of off-balance-sheet financings and special purpose entities, which should make it

\footnotetext{
${ }^{33}$ This provision could lead to a modest substitution of cash compensation for equity-based compensation. However, this would have to be accomplished entirely through salary increases because cash bonuses are also subject to the same disgorgement provisions.
} 
more difficult for companies to manipulate their financial statements in a way that boosts the current stock price.

SOX also includes a number of provisions meant to improve board monitoring. These focus largely on increasing the power, responsibility, and independence of the audit committee. SOX requires that the audit committee hire the outside auditor and that the committee consist entirely of directors with no other financial relationship with the company.

Finally, SOX increases management's and the board's responsibility for financial reporting and the criminal penalties for misreporting. The increased responsibility and penalties have clearly increased the amount of time that executives of all companies must spend on accounting matters. For companies that are already well-governed, that extra time is unnecessary and therefore costly. At least initially, some of the extra time meeting SOX's requirements will be time that could have been devoted to discussing strategy or managing the business. SOX has also caused companies to increase their use of outside accountants and lawyers. But part of the resulting increase in costs is likely to be recouped in the form of valuable new information not previously available to some CEOs, CFOs, and boards. Furthermore, the additional time and costs should decline as companies become more efficient at complying with SOX.

So, what has the new legislation really accomplished? The provisions of SOX deal both directly and indirectly with some of the deficiencies of U.S. corporate governance. But many U.S. companies would have instituted some of these changes anyway. The law already punished fraudulent reporting, including the misreporting uncovered in Enron, Tyco and WorldCom. Furthermore, the Enron scandal brought the costs of such misreporting into sharp focus before 
the passage of SOX. No CEO wants to be the CEO of the next Enron. And no board member wants to be on the board of the next Enron.

There are two potentially significant dangers associated with SOX. First, the ambiguity in some of the provisions, particularly those that overlap with and even contradict aspects of state corporate law, will almost certainly invite aggressive litigation. The fear of such litigation will lead CEOs and CFOs to direct corporate resources to protect themselves against potential lawsuits. Fear of litigation is also making it harder to attract qualified board members--certainly an unintended consequence of all the effort to improve board effectiveness. The second, broader concern is that SOX represents a shift to more rigid Federal regulation and legislation of corporate governance as distinguished from the more flexible corporate governance that has evolved from state law, particularly Delaware law. ${ }^{34}$

At this point, SOX has probably helped to restore confidence in the U.S. corporate governance system. Apart from that, the Act's expected overall effect is as yet unclear. Our guess is that the effects will be positive for companies with poor governance practices and negative for companies with good governance practices. Because some of the additional costs of complying with SOX are fixed rather than variable, the effects will be more negative for smaller companies than for larger ones. At the margin, this may lead some public companies to go private and deter some private companies from going public. And because of companies' initial uncertainty about how to comply with the Act, we expect the effects of SOX to be somewhat negative in the short term with compliance costs declining over time.

\section{NYSE and NASDAQ Corporate Governance Proposals}

\footnotetext{
${ }^{34}$ We thank Andrew Nussbaum for suggesting this possibility.
} 
In 2002, both the New York Stock Exchange and NASDAQ submitted proposals designed to strengthen the corporate governance of their listed firms. Both exchanges will require the following:

(1) shareholder approval of most equity compensation plans;

(2) a majority of independent directors with no material relationships with the company;

(3) a larger role for independent directors in the compensation and nominating committees; and (4) regular meetings of only nonmanagement directors.

Compared to SOX, these proposals address U.S. corporate governance deficiencies both more directly and with lower costs. The three provisions relating to board monitoring are particularly noteworthy in that they directly address some of the concerns mentioned by Lorsch and MacIver in 1989 and by outside directors in the Korn Ferry survey.

The closest historical parallel to these proposals is the Code of Best Practices (based upon the recommendations of the Cadbury Committee) that was adopted by the London Stock Exchange (LSE) in 1992. The Code included recommendations that boards have at least three outside directors and a nonexecutive chairperson. Although the Code is voluntary, the LSE requires companies to state whether they are in compliance.

There is evidence that the Code can make a difference. A recent study of all LSE companies reported that both CEO turnover and the sensitivity of CEO turnover to performance increased following the adoption of the Code--and that such increases were concentrated among those firms that had adopted the recommendations. Furthermore, the changes in turnover appear to have been driven by the increase in the fraction of outsiders on the board rather than the separation of the chairperson and CEO. ${ }^{35}$

\footnotetext{
${ }^{35}$ J. Dahya, J. McConnell, and Nickolaos Travlos, "The Cadbury Committee, Corporate Performance, and Top Management Turnover,” Journal of Finance, Vol. 57 (2002), pp. 461-483.
} 
Overall, then, the NYSE and NASDAQ changes should prove to be unambiguously positive.

\section{The Conference Board Recommendations}

In response to the recent scandals, the Conference Board--an association of prominent U.S. companies--put together a Commission on Public Trust and Private Enterprise with the aim of advising companies on best practices in corporate governance.

The first report by the Commission, released in September 2002, provides a set of principles to guide boards in designing top executive compensation. The report begins by noting the exceptional circumstances that led to the abuse of stock options--the equivalent of a "Perfect Storm"--and then makes the following recommendations:

(1) compensation committees should be independent and should avoid benchmarking;

(2) performance-based compensation should correspond to the corporation's long-term goals--“cost of capital, return on equity, economic value added, market share, environment goals etc."--and should avoid windfalls related to stock market volatility; (3) equity-based compensation should be "reasonable and cost effective";

(4) key executives and directors should "acquire and hold" a meaningful amount of company stock; and

(5) compensation disclosure should be transparent and accounting-neutral--i.e., stock options should be expensed. ${ }^{36}$

Overall, we have a mixed reaction to these recommendations. Several are clearly beneficial. In particular, greater transparency and appropriate expensing of options will make 
the costs of options more clear not only to shareholders but also to boards. It also will "level the playing field" for options versus other forms of equity-based compensation.

Requiring key executives to hold a meaningful amount of company stock will reduce the temptation to manipulate earnings and stock prices in the short term by making executive stock holdings less liquid. Typically, stock options vest in one to four years, which is short given that most options are exercised and sold fairly soon after vesting. Economic logic suggests that boards should encourage longer-term holdings and a build-up of sizable executive stakes.

The Commission also endorses indexation of some kind to eliminate windfall gains. Indexation has been recommended by economists for a long time, yet practitioners have not adopted it. It is true that there has been an important accounting disadvantage to indexation in that indexed options must be expensed. But the fact that indexed options are rarely used by LBO investors and venture capitalists also suggests that there are hidden costs to indexation or that the benefits are low.

While it may be useful to experiment with some forms of indexation, we think it would probably be just as effective and more transparent to index implicitly by granting stock-based incentives more frequently and in smaller amounts. Mega-grants covering several years at a fixed price have proved too unstable; the options may go underwater and then need to be bailed out (to maintain incentives), making it hard initially to determine the true expected cost of the incentive plans. In general, the incentives from stock options are more fragile than those

\footnotetext{
${ }^{36}$ Andy Grove, Chairman of Intel, disagreed with the majority in not recommending expensing of stock options, while Paul Volcker, former Chairman of the Board of Governors of the Federal Reserve System, argued that fixedprice stock options should not be used at all. Both filed dissenting opinions.
} 
provided by restricted stock, a problem that more frequent, smaller awards would help alleviate. $^{37}$

We are also skeptical of the recommendation to use performance-based compensation tied to a long list of potential long-term goals, including cost of capital, return on equity, market share, revenue growth, and compliance and environmental protection goals. Such performance plans would appear to take us back to the 1970s, an era that few incentive experts remember fondly. If the problem is windfall gains, then indexed stock options or, more simply, frequent (quarterly) issues of stock options are much preferred. If the problem is manipulation of the market, it should be evident that accounting measures of the kind endorsed by the Conference Board are very problematic. It was in large part because of their vulnerability to manipulation that standard performance plans were replaced by stock-based incentives in the 1980s. This is not to say that accounting-based incentives should never be used, just that they should not form the core of a CEO's incentive plan.

We are also somewhat skeptical of the recommendation that the compensation committee "act independently of management...and avoid benchmarking that keeps continually raising the compensation levels for executives." First, dictating terms without consulting with the executives about their preferences goes against efficient contracting principles; contracting is a two-sided affair. Second, the intent seems to be to give individual compensation committees the responsibility for the overall level of executive compensation. But it is hard to see how pay levels can be set in a fair and efficient way without benchmarking. Prices, including wages, are

\footnotetext{
${ }^{37}$ See Brian Hall and Thomas Knox, "Managing Option Fragility," Harvard NOM Research Paper 02-19, Harvard Business School (2002). It is interesting that fairness arguments often lead people to advocate options with exercise prices set well above current market price (for instance, Michael Jensen argues that the exercise price should rise with the cost of capital). Given the problems of fragility, this takes us in exactly the wrong direction. Restricted stock (an option with a zero exercise price) is more appealing, because its incentive effect is robust to variations in the stock price.
} 
ultimately set by supply and demand, and benchmarking is nothing more than looking at market prices. The main problem with executive pay levels is not the overall level, but the extreme skew in the awards, as we noted earlier. To deal with this problem, we need more effective benchmarking, not less of it.

Despite good intentions, then, we see potentially serious flaws in the recommendations of the Conference Board. It is also important to keep in mind that good incentive designs are sensitive to economic circumstances and to the desired performance. One size does not fit all. And because each situation requires its own compensation plan, the need to customize that plan will often conflict with the goals of benchmarking and transparency.

\section{WHAT WILL THE FUTURE BRING?}

Working together with normal market forces, the Sarbanes-Oxley Act, the new NYSE and NASDAQ regulations, and the guidelines offered by groups like the Conference Board will significantly influence U.S. corporate governance.

Board behavior will be most strongly affected by these measures. External pressure will lead most boards to monitor top management more aggressively. Yet the relationship between boards and directors need not become more adversarial. The new regulatory requirements provide cover for a more independent and inquisitive board. Actions that in the past might have been construed as hostile will now be interpreted as following best practice. The mandated changes may in fact help reduce the tension inherent in the dual role boards play as monitors of management, on the one hand, and as advisors and sounding boards, on the other.

In addition to the changes in oversight and monitoring, boards also are likely to change their approaches to executive compensation (even though SOX and the exchanges did not 
address executive compensation directly). In particular, boards will increasingly restrict top executives from exercising options, selling stock, and hedging their positions. As noted earlier, some of the incentives for the executives at Global Crossing, Tyco, and WorldCom to manage earnings came from their ability to sell shares when their stock prices were overvalued. Restrictions on such selling reduce the incentive to manage short-term earnings. While such restrictions have costs, particularly in the form of lack of diversification, the benefits in terms of improved incentives arguably outweigh them. Private equity firms routinely impose such restrictions on the management of their portfolio companies. Furthermore, CEOs typically are wealthy enough that the benefits of diversification may not be so great.

Many corporate boards will decide to expense options and equity compensation even if they are not required to do so. We suspect that boards will discover that investors and the stock market have neutral or even positive reactions to such expensing (in contrast to the predictions of many executives). Sophisticated investors already know the extent of option issuance from their disclosure in footnotes. Expensing will provide the additional signal to sophisticated investors that the board and the company are serious about compensation and corporate governance. ${ }^{38}$

Boards of directors and compensation committees also will begin to change their behavior in issuing options and equity-based compensation. This will be particularly true of boards that decide to expense options. Expensing the options will make their costs more clear and will reduce the size of option grants, particularly large, onetime grants. Moreover, some companies that do expense equity compensation will choose to issue restricted stock rather than options. Restricted stock grants have the advantages of being easier to value, providing

\footnotetext{
${ }^{38}$ The argument that options cannot be expensed because no one knows their true value is wrong. On that basis, one could argue that we should not depreciate assets because it is impossible to measure the assets' true rate of depreciation. Nevertheless, it remains to be seen how fluctuations in the value of stock options will influence the
} 
incentives that do not vary with stock price movements, and thus being less vulnerable to repricing. ${ }^{39}$

\section{CONCLUDING REMARKS}

Despite its alleged flaws, the U.S. corporate governance system has performed very well, both on an absolute basis and relative to other countries. It is important to recognize that there is no perfect system and that we should try to avoid the pendulum-like movement so typical of politically inspired system redesigns. The current problems arose in an exceptional period that is not likely to happen again soon. After all, it was almost 70 years ago that the corporate governance system last attracted such intervention.

The fact that the American public and political system became outraged and involved in corporate governance does not mean the system was broken. The U.S. public and the political system are part of the broader system of corporate governance. At the same time, an effort to regulate the system so that such outrage will never again occur would be overly costly and counterproductive. It would lead to inflexibility and fear of experimentation. In today's uncertain climate, we probably need more organizational experimentation than ever. The New Economy is moving forward and, in order to exploit the potential efficiencies inherent in the new information technologies, new business models and new organizational structures are likely to be desirable and valuable. Enron was an experiment that failed. We should take advantage of its lessons not by withdrawing into a shell, but rather by improving control structures and corporate governance so that other promising experiments can be undertaken.

information content of reported earnings. The never-ending debate over the best way to handle depreciation suggests that expensing options is going to be discussed for years to come.

${ }^{39}$ See Hall (2002), ibid, for a detailed discussion. 
Table 1

Stock Market Performance

Stock returns reported by Ibbotson Associates for total return on Morgan Stanley Capital International (MSCI) Indices for the United States, Europe, Pacific, Great Britain, France, Germany, and Japan from January 1 of the given year through end of December 2002.

\begin{tabular}{|c|c|c|c|c|c|}
\hline & $\underline{\text { U.S. }}$ & Europe & \multicolumn{2}{|c|}{$\underline{\text { Pacific }}$} & \\
\hline From 1982 (January) & $1222 \%$ & $1145 \%$ & \multicolumn{2}{|c|}{$276 \%$} & \\
\hline From 1987 & $436 \%$ & $266 \%$ & \multicolumn{2}{|c|}{$3 \%$} & \\
\hline From 1992 & $164 \%$ & $113 \%$ & \multicolumn{2}{|c|}{$-27 \%$} & \\
\hline From 1997 & $28 \%$ & $13 \%$ & \multicolumn{2}{|c|}{$-39 \%$} & \\
\hline From 2001 & $-32 \%$ & $-34 \%$ & \multicolumn{2}{|c|}{$-32 \%$} & \\
\hline & $\underline{\text { U.S. }}$. & $\begin{array}{l}\text { Great } \\
\text { Britain }\end{array}$ & $\underline{\text { France }}$ & Germany & $\underline{\text { Japan }}$ \\
\hline From 1982 & $1222 \%$ & $1223 \%$ & $1567 \%$ & $595 \%$ & $90 \%$ \\
\hline From 1987 & $436 \%$ & $290 \%$ & $236 \%$ & $93 \%$ & $-37 \%$ \\
\hline From 1992 & $164 \%$ & $121 \%$ & $147 \%$ & $84 \%$ & $-42 \%$ \\
\hline From 1997 & $28 \%$ & $11 \%$ & $47 \%$ & $5 \%$ & $-39 \%$ \\
\hline From 2001 & $-32 \%$ & $-32 \%$ & $-45 \%$ & $-53 \%$ & $-34 \%$ \\
\hline
\end{tabular}

Table 2

Changes in Real GDP per Capita

Changes in real GDP per capita for the U.S., the U.K., France, Germany and Japan. Calculated using the Penn World Tables.

\begin{tabular}{|c|c|c|c|c|c|}
\hline & $\underline{\text { U.S. }}$ & $\begin{array}{l}\text { Great } \\
\text { Britain } \\
\end{array}$ & France & Germany & $\underline{\text { Japan }}$ \\
\hline From 1982 (beginning) to 2000 & $54 \%$ & $58 \%$ & $37 \%$ & $44 \%$ & $55 \%$ \\
\hline From 1987 to 2000 & $38 \%$ & $36 \%$ & $28 \%$ & $29 \%$ & $36 \%$ \\
\hline From 1992 to 2000 & $29 \%$ & $24 \%$ & $12 \%$ & $12 \%$ & $8 \%$ \\
\hline From 1997 to 2000 & $14 \%$ & $11 \%$ & $11 \%$ & $8 \%$ & $3 \%$ \\
\hline
\end{tabular}




\section{References}

Becht, Marco, Patrick Bolton, and Ailsa Roell, 2002, “Corporate Governance and Control,” Handbook of Economics and Finance, Constantinides, Harris and Stulz, eds. North Holland.

Bebchuk, Lucian, Jesse Fried and David Walker, 2002, "Managerial Power and Rent Extraction in the Design of Executive Compensation," University of Chicago Law Review 69, 751-846.

Core, J. and D. Larcker, 2002, "Performance consequences of mandatory increases in executive stock ownership," Journal of Financial Economics.

Dahya, J., J. McConnell, and N. G. Travlos, 2002, “The Cadbury Committee, Corporate Performance, and Top Management Turnover," Journal of Finance, 57, pp. 461-483.

Donaldson, G. and J. Lorsch. 1983. Decision Making at the Top. Basic Books, New York, New York.

Donaldson, G. 1994. Corporate Restructuring. Harvard Business School Press, Boston, MA.

Escherich R. and P. Gibbs, 2002, Global Mergers and Acquisitions Review. JP Morgan, April.

Felton, B., A. Hudnut, and J. Von Heeckeren. 1997. “The Dollar Value of Board Governance.” Mckinsey Quarterly.

Fried J. and D. Walker, 2002, "Managerial Power and Rent Extraction in the Design of Executive Compensation," University of Chicago Law Review, 751-846.

Gertner, R., and S. Kaplan. 1996. “The Value-Maximizing Board.” Working Paper, University of Chicago.

Gillan, S., and L. Starks. 2000. "Corporate Governance Proposals and Relationship Shareholder Activism: The Role of Institutional Investors.” Journal of Financial Economics. 57, No. 2, pp. 275-305.

Gompers, Paul and Andrew Metrick. 2001. "Institutional Investors and Equity Prices.” Quarterly Journal of Economics, Vol 116 (1), 2001, 229-260.

Gompers, Paul, Joy Ishi, and Andrew Metrick. 2001. “Corporate Governance and Equity Prices”, Working Paper 8449, NBER, 2001.

Hall, B. 2002, “Equity-Pay Design for Executives,” working paper, Harvard Business School (2002)

Hall, B. and T. Knox, “Managing Option Fragility,” Harvard NOM Research Paper 02-19, Harvard Business School. (2002)

Hall, B., and J. Liebman. 1998. “Are CEOs Really Paid like Bureaucrats?” Quarterly Journal of Economics. 112 , No. 3, pp. 653-691.

Hall, B., and J. Liebman. 2000. “The Taxation of Executive Compensation.” Working Paper, National Bureau of Economic Research.

Hall, B. and K. Murphy, 2002, "Stock options for undiversified executives," Journal of Accounting and Economics, $3-42$.

Hermalin, B. and M. Weisbach. 2001. Boards of Directors as an Endogenously Determined Institution: A Survey of the Economic Literature.

Holderness, C., R. Kroszner, and D. Sheehan. 1999. Were the Good Old That Good? Changes in Managerial Stock Ownership Since the Great Depression. Journal of Finance. 54:2, pp. 435-470. 
Holmstom, B. and S. Kaplan, 2001, "Corporate Governance and Takeovers in the U.S.: Making sense of the " 80 s and '90s," Journal of Economic Perspectives, Spring, 121-144.

Huson, M., Parrino, R., and Starks, L., 2001, "Internal Monitoring Mechanisms and CEO Turnover: A Long Term Perspective.” Journal of Finance 56, 2265-2297.

Jensen, M. 1988. “Takeovers: Their Causes and Consequences.” Journal of Economic Perspectives. 2, pp. 21-48.

Jensen, M. 1989. “The Eclipse of the Public Corporation.” Harvard Business Review. No. 5, pp. 61-74.

Jensen, M. 1993. “The Modern Industrial Revolution.” Journal of Finance, 48:3, 831-80.

Jensen, M. and M. Fuller, 2002, “Just Say No to Wall Street," Working paper, Harvard Business School.

Karpoff J., 1998, "The Impact of Shareholder Activism on Target Companies: A Survey of Empirical Findings," Working paper, University of Washington.

Kaplan, S. 1989. "The Effects of Management Buyouts on Operations and Value.” Journal of Financial Economics. 24, pp. 217-254.

Kaplan, S. 1997. “The Evolution of U.S. Corporate Governance: We Are All Henry Kravis Now.” Journal of Private Equity, 7-14.

Kaplan, S. and A. Schoar, 2002, "Private Equity Returns: Persistence and Capital Flows,” working paper, University of Chicago, December.

Khurana, R. 2002, Searching for a corporate savior: The Irrational Quest for Charismatic CEOs. Princeton University Press.

Khurana, R. and N. Nohria, 1997, "Substance and symbol: The Effects of CEO Turnover in Large Industrial Organizations," working paper, Harvard Business School.

Lorsch, J. and E. MacIver. 1989. Pawns or Potentates. Harvard Business School Press.

Mitchell, M. and H. Mulherin. 1996. "The Impact of Industry Shocks on Takeover and Restructuring Activity.” Journal of Financial Economics. pp. 193-229.

Murphy, Kevin J. 1999. “Executive Compensation.” In O. Ashenfelter and D. Card (eds.), Handbook of Labor Economics. Volume 3, North Holland, pp. 2485-2525.

Perry, T. 2000. "Incentive compensation for outside directors and CEO turnover." Working paper, Arizona State University.

Perry, T., and M. Zenner. 2000. “CEO Compensation In The 1990s: Shareholder Alignment Or Shareholder Expropriation?" Wake Forest Law Review.

Porter, M. 1992, “Capital Disadvantage: America’s Failing Capital Investment System,” Harvard Business Review, September-October, 65-83.

Poterba, J. and A. Samwick, 1995, "Stock Ownership Patterns, Stock Market Fluctuations, and Consumption." Brookings Papers on Economic Activity. 2, 295-357.

Rajan, R. and J. Wulf, 2002, “The Flattening Firm,” working paper, University of Chicago.

Rogers, P., T. Holland and D. Haas, 2002, "Value Acceleration: Lessons from Private-Equity Masters," Harvard Business Review, June. 
Stein, J., 1989, "Efficient Capital Markets, Inefficient Firms: A Model of Myopic Corporate Behavior," The Quarterly Journal of Economics, Vol. 104, 655-669.

Yermack, David. 1996. "Higher market valuation of companies a small board of directors." Journal of Financial Economics. 40, pp. 185-202. 